\title{
LÉGKÖRI JEGESEDÉSNEK KITETT VILLAMOS TÁVVEZETÉKEK NUMERIKUS VIZSGÁLATA
}

\author{
KÁLMÁN TAMÁS \\ $\mathrm{PhD}$, projektmenedzser. GEA EGI Energiagazdálkodási Zrt. 1117 Budapest, Irinyi József u. 4-20. \\ Tel.: (+36-30) 822-3460; fax: (+36-1) 225-6264. E-mail: tamas.kalman@gea.com
}

\begin{abstract}
Azokban az országokban, ahol a légköri jegesedés gyakorta okoz komoly károkat a mérnöki építményekben, komoly hangsúlyt fektetnek e tudományterület alapos megismerésére és olyan technológiák, eljárások kifejlesztésére, amelyekkel a katasztrófák elkerülhetőek vagy legalábbis hatásuk mérsékelhető. A mérnöki építmények egyik ilyen, légköri jegesedésnek kitett szegmense a villamos energiaátviteli hálózatokon alkalmazott berendezések, szerkezetek. Ezen építmények megrongálódásáért a téli időszakban gyakran felelős a szerkezetekre rakodó jég, tapadó hó vagy zúzmara. Jelen tanulmány általános összefoglalót kíván adni a villamos energiaátviteli hálózatot érintő légköri jegesedésröl és egy olyan eljárásról, mellyel a távvezetékre rakódott jég mechanikus erő, azaz ütés hatására eltávolítható. A szerző egy olyan eljárást dolgozott ki a jeges távvezetékek numerikus vizsgálatára, mely modellezi az ütés hatására bekövetkező jéghullás okozta dinamikus hatásokat, úgy, hogy figyelembe veszi a kábelre rakódott jég mechanikai tulajdonságait. A szerző Kanadában, a CIGELE kutatócsoport keretében végzett $\mathrm{PhD}$ tanulmányainak eredményét használta fel jelen tanulmány megírására, kiegészítve azt a témában az óta elért új tudományos eredményekkel.
\end{abstract}

Kulcsszavak: villamos távvezeték, légköri jegesedés, dinamikus vizsgálat, végeselem-modell

\section{BEVEZETÉS}

Egyre világosabb tudományos eredmények vannak arra vonatkozóan, hogy a föld légköre jelentős változáson megy keresztül, mely - komplex folyamatok révén - öszszességében klímaváltozáshoz vezet. A klímaváltozás következtében az extrém időjárási jelenségek kockázata - számos egyéb jelenséggel együtt - növekszik. Így hideg klímájú területeken egyre növekedhet a légköri jegesedés okozta problémák gyakorisága.

Hideg klímájú területeken a légköri jegesedés egy gyakori jelenség, melyet hagyományosan kétféle képződési folyamat alapján osztályozunk; megkülönböztetünk felhőn belüli és csapadékból származó jegesedést. Főleg a felszín tereptárgyain mikro- vagy makrocsapadék által okozott jeges lerakódás formájában figyelhető meg, általában 0 és $-10^{\circ} \mathrm{C}$ közötti, vagy néha annál alacsonyabb hőmérsékleten. A felszíni jegesedés leggyakoribb megjelenési formája a (atmoszferikus) jég, zúzmara (durva vagy finom), tapadó hó, száraz hó és a dér. A felszíni jegesedés megjelenési formáját és annak mértékét nagymértékben befolyásolja a környezeti hőmérséklet, szélsebes- 
ség, a levegő nedvességtartalma és a csapadék cseppmérete. Ezek a különböző típusú jegesedési formák, képződmények más és más tulajdonságokkal bírnak (Kálmán 2007).

Jelen tanulmány a légköri jegesedés többféle formája közül kifejezetten a jégre koncentrál, mely leggyakrabban ónos eső formájában hulló csapadékból pár óra leforgása alatt jelentős mennyiségben tapadhat a villamos energiaátviteli hálózat berendezéseire, szerkezeteire. A szerkezetekre, villamos távvezetékekre tapadó jég számos mechanikai és elektromos probléma forrása lehet. Csupán néhány mechanikai problémát megemlítve: a távvezetékekre és tartószerkezetekre rakodó jég nehéz tömege, párosulva az egyidejüleg jelentkező szélterheléssel, komoly szerkezeti meghibásodásokhoz, törésekhez, vezetőszakadásokhoz vagy akár a tartóoszlopok kaszkád töréseihez vezethet.

Abban az esetben, amikor a vezetékre tapadt jég arról valamilyen módon leesik, kialakul az ún. jéghullás jelensége, melyet összességében a szerkezetre tapadt jég tömegének valamilyen módú csökkenése jellemez. Három ilyen mechanizmust különböztetünk meg: jégolvadás, jég szublimáció, valamint mechanikai jégtörés (Kálmán 2007). Mechanikai jégtörés - melyre jelen tanulmány fókuszál - létrejöhet egy külső erő hatására (akár valamely más tárggyal való véletlen ütközésből, akár abból a szándékból, hogy a jeget eltávolítsák).

Annak érdekében, hogy a villamos energiaátviteli hálózatot megvédjék a jég okozta - akár elektromos, akár mechanikai - terheléstől, számos olyan módszert alkalmaznak világszerte, mely megelőzi a távvezetékek jegesedését, vagy eltávolítja a már a vezetékre tapadt jeget (Kálmán 2007). A leggyakrabban alkalmazott módszer a jég leolvasztása, mely azonban többnyire csak nagyfeszültségü hálózatokon alkalmazható. Középfeszültségü hálózatokon, valamint a földelő vezetékeken jégolvasztás gazdaságosan gyakorlatilag nem valósítható meg. Ezért a québeci áramszolgáltató, Hydro-Québec számos olyan mechanikai eljárást fejlesztett ki és használ, mely a földelő vezetékekre rakódott jeget hivatott eltávolítani. Az egyik ilyen kifejlesztett eszköz (1. ábra), mely jelen tanulmány megszületését inspirálta, mechanikai ütést használ a jég eltávolítására kihasználva a jég nagy alakváltozási sebességen tapasztalható rideg törékeny tulajdonságait. A fejlesztők szándéka szerint ezzel az eszközzel egyszerre egy fesztávnyi vezetékről lehet a jeget eltávolítani (Leblond et al. 2005).

A tanulmány célja az volt, hogy megértsük az ütés okozta jéghullás távvezetékre gyakorolt dinamikus hatásait egy végeselem-módszerrel fejlesztett numerikus modell segítségével. Ezért ebben a tanulmányban a távvezetéket érő mechanikai ütés egy külső, impulzus típusú erőhatásból származik, mely a vezetékre tapadt jeget szándékozik eltávolítani. Ilyen dinamikus terhelés azonban származhat spontán, hirtelen jéghullásból, vezetékszakadásból vagy valamilyen tartó komponens (pl. állószigetelö) töréséből eredő aszimmetrikus terhelésből is. Míg korábbi numerikus modellfejlesztések (Jamaleddine et al. 1993; Roshan Fekr 1995; McClure-Lapointe 2003) során a vezeték azonnali jéghullásra adott válaszát tanulmányozták, ez a tanulmány a jéghullás nyomvonal irányú fokozatos terjedésének hatását vizsgálta (Kálmán 2007; Kálmán et al. 2005; 2007a; 2007b). 


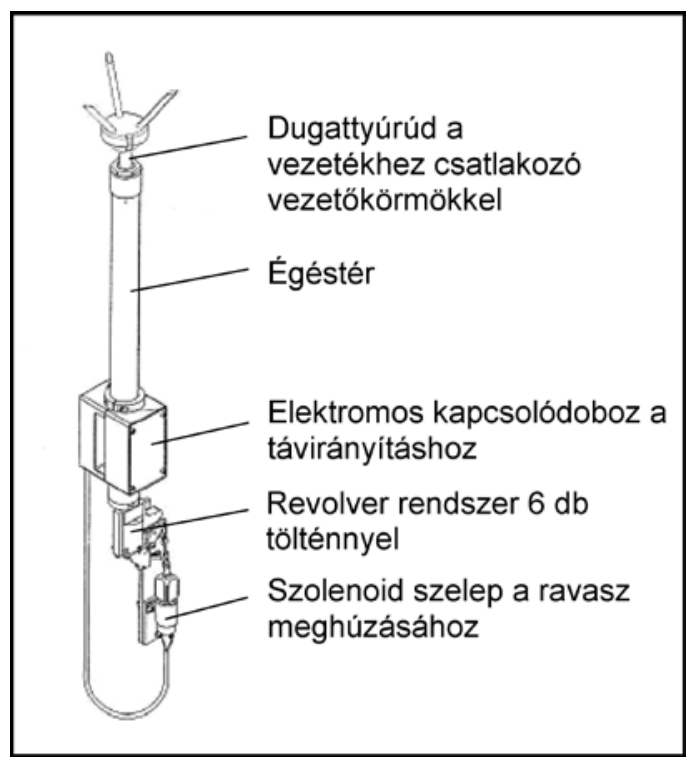

1. ábra. Hydro-Québec által fejlesztett jégeltávolító eszköz sematikus rajza (Forrás: Leblond et al. 2005)

Magyarországon is okozott már problémát a távvezetékek jegesedése, mely komoly üzemzavarok formájában nyilvánult meg (Szabó-Farkas 2009; Pekánovics et al. 2011; Index 2014). Hazai megfigyelések szerint, mechanikai túlterhelés esetén a tartószerkezet leggyengébb eleme az oszlop (Pekánovics et al. 2011). Ezért kísérletek folytak olyan konstrukciók kialakítására, melyek extrém időjárási körülmények között bekövetkezö üzemzavar esetén csökkentik az oszlopra ható nyomvonal irányú többletterhelést meghibásodásra kitüntetett elemek, valamint rugalmasabb hálózati konfigurációk kialakításával (Pekánovics et al. 2011). A jelen tanulmányban javasolt numerikus modell alkalmazása, esetleges továbbfejlesztése a hazai villamos energiaátviteli hálózat fejlesztői, tervezői számára is hasznos eszköz lehet.

\section{A NUMERIKUS MODELL}

A korábbi idegen nyelvű publikációimban (Kálmán et al. 2005; 2007a; 2007b) részletesen bemutattam a kereskedelmi forgalomban kapható, ADINA rendszerben fejlesztett végeselem-modellt, mely a jeges kábelt szimulálja és új megközelítésként a jégtörés feltételét is a modellbe integrálja. Ez a modell alapul szolgált arra, hogy a jég törési feltételét tanulmányozzuk az alakváltozás okozta feszültség függvényében, mely magába foglalja mind az axiális, mind pedig a hajlító hatásokat. Ebben a fejezetben bemutatom a numerikus modellt. A fejezet végén pedig a $\mathrm{PhD}$ tanulmányaim 
befejezése óta a modell továbbfejlesztésében mások által elért új eredményeket, numerikus megközelítéseket is ismertetem.

\subsection{A TÁVVEZETÉK MODELLEZÉSE}

Korábbi numerikus modellfejlesztések (Jamaleddine et al. 1993; Roshan Fekr 1995; McClure-Lapointe 2003) jó tapasztalatai alapján a modell feltételezi, hogy a vezeték hajlításra és csavarásra teljesen rugalmas. Ezért 3D-s, két csomópontú, izotrop rúd-elemmel modelleztem úgy, hogy a modell a teljes Lagrange-formulát használja nagy kinematikai elmozdulással, de kis alakváltozással. Minden vezetékelemnek négy szabadságfoka van, ami megfelel az elem végeinek vízszintes és függőleges irányú eltolódásával. A vezeték anyagát tekintve lineárisan rugalmas, és csak húzásra van igénybe véve, így biztosítva azt, hogy a vezeték bármikor elernyedjen, ha az előfeszítő erő megszünik. A végeselemháló sürüségét és az időlépést úgy választottam meg, hogy biztosítsa az ütés, valamint az általa generált hullám terjedésének megfelelő mintavételezését a modell integrációs pontjain keresztül. A vezeték kezdeti előfeszítését előzetes statikai számításokból határozom meg (Kálmán 2007).

\subsection{A VEZETÉKRE TAPADT JÉG MODELLEZÉSE}

A vezetékre tapadt jeget egy, a vezetékelemmel párhuzamos, különálló gerendaelemmel modelleztem (2. ábra). A 3D-s, izotrop gerendaelem, képlékeny anyagjellemzőkkel megfelelőnek bizonyult a feladatra. Minden gerendaelemnek hat szabadságfoka van, ami megfelel az elem végeinek vízszintes és függöleges irányú eltolódásával, ill. síkbeli elfordulásával. Mivel ADINA-ban az izotrop gerendaelemhez csak négyszögletes keresztmetszetet lehetett használni a nemlineáris anyagmodellekhez, így a jeget képviselő gerendaelem keresztmetszetét úgy határoztam meg, hogy azonos hajlítómerevséget és keresztmetszeti területet eredményezzen a vezetékre rakódott, idealizált keresztmetszetü jég hajlítómerevségével és keresztmetszeti területével (3. ábra). A tartócsomópontokban a modell semmilyen elmozdulást nem enged meg. Így annak érdekében, hogy a modell a jég gerendaelem ebből eredő zavaró merevítő hatását kiküszöbölje, a tartócsomópontok mellett jég gerendaelemeket nem definiáltam.

Ezen felül két alternatív jégelem használatának lehetőségét is megvizsgáltam, úgy, mint a 2D-s, sík feszültségü, izotrop gerendaelem, valamint a csőelem. Mindkét elem megfelelőnek bizonyult a feladatra. A 2D-s, sík feszültségü, izotrop gerendaelem használata nagymértékben csökkenti a modell futásidejét. Azonban ennek az elemnek a használatával kapott eredményeket körültekintően kell értékelni akkor, amikor a modell részleges jégtörést prognosztizál. Ennek az elemnek a használata hajlamos a nyírófeszültséget túlbecsülni a húzófeszültséggel szemben, és így kiala- 


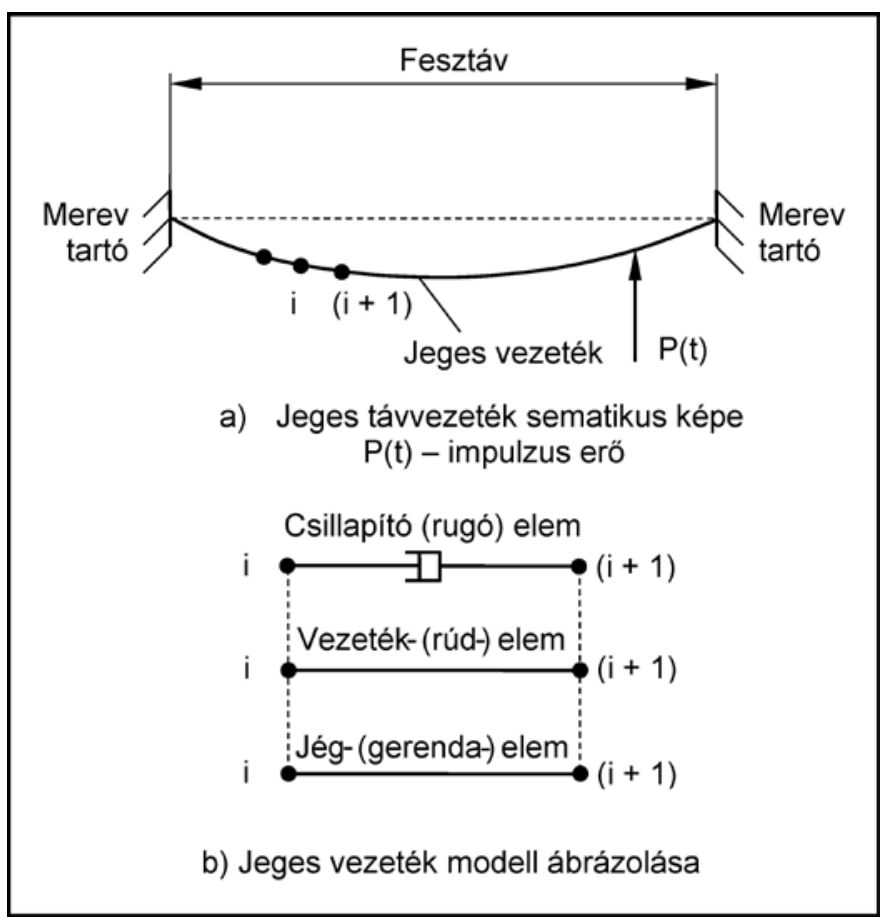

2. ábra. Jeges vezeték sematikus modellképe

kul az ún. „shear locking” hatás (Kálmán 2007; Kálmán et al. 2007a). A csőelem használatának egyik nagy előnye, hogy nincsenek a keresztmetszetre vonatkozó korlátozások, és a kapott eredmények is jó azonosságot mutatnak a 3D-s, izotrop gerendaelemmel kapott eredményekkel. Tanulmányaim során, valamint korábbi idegen nyelvü publikációim kapcsán (Kálmán 2007; Kálmán et al. 2005; 2007a; 2007b) mindhárom jégelem használatával számos modellfuttatást végeztem és az eredményeket kiértékeltem, összehasonlítottam.

\subsection{A JÉGTÖRÉS MODELLEZÉSE}

A jég törését és az azt követő jéghullást az ADINA-ban rendelkezésre álló „,element death upon rupture" opcióval oldottam meg. Ennek a lényege az, hogy az opció automatikusan aktiválódik, amikor a törési kritérium bármely integrációs pontban teljesül. A törési kritérium teljesülését követő számításokban az adott elemet a szoftver „halottnak” tekinti és az adott elem tömegének, valamint merevségének hatását automatikusan törli a modellből. A 3D-s, izotrop gerendaelemet két lineáris szakaszból álló elasztoplasztikus anyagmodellel definiáltam az alábbi para- 
a)

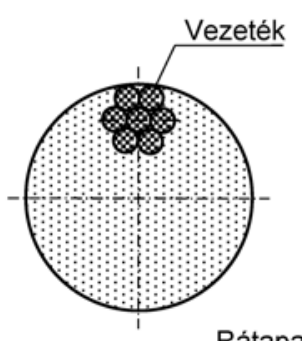

b)

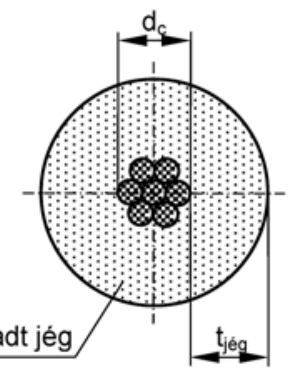

c)

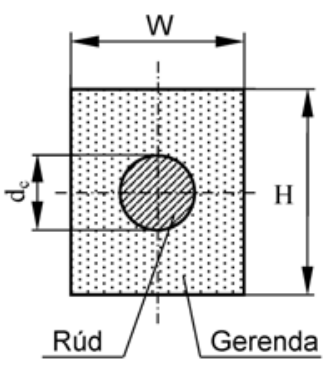

$$
\begin{array}{ll}
I_{t}=\frac{\left(\left(d_{c}+2 \cdot t_{j e g}\right)^{4}-d_{c}^{4}\right) \cdot \pi}{64} & I_{t}=\frac{H \cdot W^{3}}{12} \\
A=\frac{\left(\left(d_{c}+2 \cdot t_{j \dot{ }}\right)^{2}-d_{c}^{2}\right) \cdot \pi}{4} & A=H \cdot W
\end{array}
$$

3. ábra. A vezetékre tapadt jég és annak modellábrázolása: a) Mesterséges jégréteg a vezetéken;

b) Vezetékre tapadt jég idealizált alakja; c) A jég izotrop gerendaelemmel való ábrázolása

(azonos hajlítómerevség és keresztmetszeti terület)

méterekkel: rugalmassági modulus (E) $10 \mathrm{GPa}$; Poisson-tényező (v) 0,3; sürüség $(\rho)$ $900 \mathrm{~kg} / \mathrm{m}^{3}$; folyáshatár $\left(\sigma_{\mathrm{F}}\right) 2 \mathrm{MPa}$ és a megengedett maximális plasztikus alakváltozás $(\varepsilon) 10^{-10}$.

\subsection{CSILLAPÍTÁS}

Korábbi numerikus modellfejlesztések (Jamaleddine et al. 1993; Roshan Fekr 1995; McClure-Lapointe 2003) jó tapasztalatai alapján az aerodinamikai csillapítást a modell elhanyagolja, és csupán a jeges vezeték axiális irányú szerkezeti csillapítását veszi számításba. Így a csillapítást egy nemlineáris, különálló axiális rugóelemmel modelleztem, mint egy, a vezetékelemmel párhuzamos csillapító elem (2. ábra). A csillapítási tényezőt úgy határoztam meg, hogy megfeleljen egy Hooke-test 2\%-os kritikus axiális csillapításának (Kálmán 2007).

A vezeték szerkezeti csillapítása mellett a modell numerikus csillapítást is alkalmaz annak érdekében, hogy kiszürje a rendszer végeselem számításból származó hamis, nagy frekvenciájú válaszait. A numerikus csillapítás a dinamikus egyensúlyi egyenletek megoldására választott Newmark-féle idő-integrációs algoritmus paramétereivel ( $\delta$ és $\alpha$ ) történik (4. ábra). Számos integrációs és iterációs algoritmus alkalmazásának, valamint azok különböző meghatározó paramétereinek a modellre gyakorolt hatását tanulmányoztam (1. táblázat), és ezek alapján a Newmark-féle integrációs algoritmust ajánlom $\delta=0,55$ és $\alpha=0,3$ értékek és a teljes Newton-féle iterációs eljárás alkalmazásával (Kálmán 2007). 


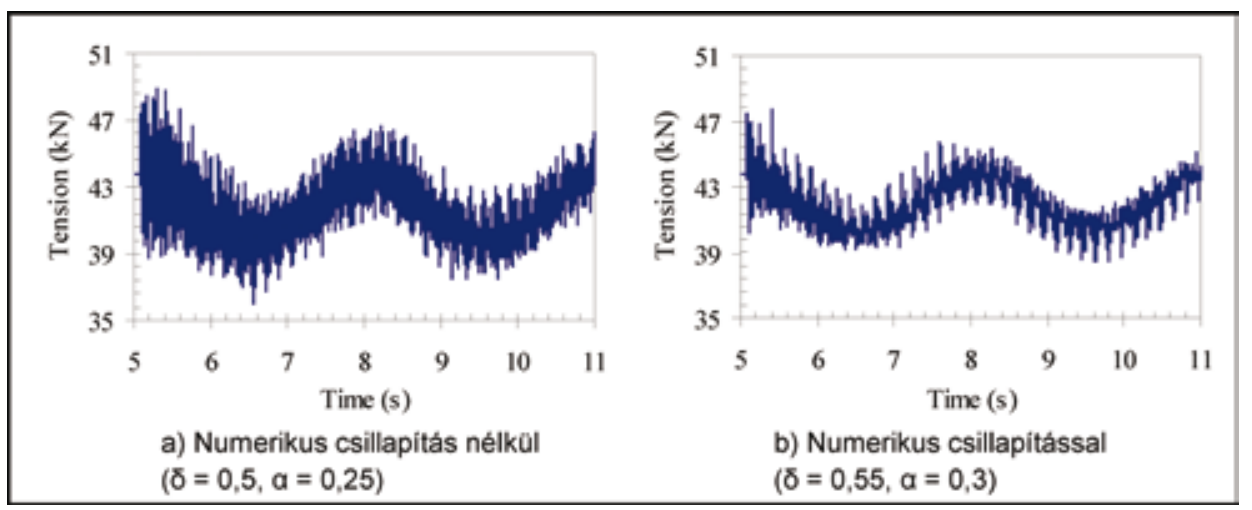

4. ábra. Vezeték irányú feszültség változása az idő függvényében a Newmark-féle integrációs algoritmus használatával (Forrás: Kálmán 2007)

1. táblázat. Modelleredmények különböző numerikus paraméterek alkalmazásával ugyanarra a jeges távvezeték konfigurációra

\begin{tabular}{|c|c|c|c|c|c|}
\hline \multirow{2}{*}{$\begin{array}{l}\text { Integrációs } \\
\text { paraméterek }\end{array}$} & \multirow{2}{*}{ Iterációs algoritmus } & \multicolumn{4}{|c|}{ 3D-s, izotrop gerendaelem } \\
\hline & & JHA & HKA & MF & ME \\
\hline \multirow{3}{*}{$\begin{array}{l}\delta=0,5 \\
\alpha=0,25\end{array}$} & Módosított Newton & 100 & 0,071 & 77,8 & 1,23 \\
\hline & BFGS Mátrix Update & 100 & 0,069 & 76,9 & 1,28 \\
\hline & Teljes Newton & 100 & 0,071 & 77,8 & 1,13 \\
\hline \multirow{3}{*}{$\begin{array}{l}\delta=0,5 \\
\alpha=0,3\end{array}$} & Módosított Newton & 100 & 0,070 & 78,4 & 1,17 \\
\hline & BFGS Mátrix Update & 100 & 0,069 & 78,2 & 1,24 \\
\hline & Teljes Newton & 100 & 0,069 & 78,4 & 1,18 \\
\hline \multirow{3}{*}{$\begin{array}{l}\delta=0,5 \\
\alpha=0,35\end{array}$} & Módosított Newton & 100 & 0,071 & 78,7 & 1,15 \\
\hline & BFGS Mátrix Update & 99 & 0,070 & 76,3 & 1,10 \\
\hline & Teljes Newton & 100 & 0,070 & 78,7 & 1,27 \\
\hline \multirow{3}{*}{$\begin{array}{l}\delta=0,55 \\
\alpha=0,3\end{array}$} & Módosított Newton & 85 & 0,072 & 77,2 & 0,86 \\
\hline & BFGS Mátrix Update & 84 & 0,075 & 76,9 & 0,85 \\
\hline & Teljes Newton & 84 & 0,074 & 77,2 & 0,85 \\
\hline \multirow{3}{*}{$\begin{array}{l}\delta=0,55 \\
\alpha=0,35\end{array}$} & Módosított Newton & 83 & 0,078 & 77,4 & 0,87 \\
\hline & BFGS Mátrix Update & 85 & 0,067 & 77,6 & 0,91 \\
\hline & Teljes Newton & 84 & 0,075 & 77,4 & 0,90 \\
\hline
\end{tabular}

JHA - jéghullás aránya (\%); HKA - ütés által generált hullám kezdeti amplitúdója (m); MF - maximális vezeték irányú feszültség $(\mathrm{kN})$; $\mathrm{ME}$ - maximális vezeték (ugrás) eltolódás $(\mathrm{m})$ (Forrás: Kálmán 2007) 


\subsection{EGYÉB MEGFONTOLÁSOK}

Annak érdekében, hogy a modell a jéggel terhelt kezdeti statikus egyensúlyi vezetékképet, profilt hủen számolja, a jég- (gerenda-) elem hajlítómerevségéből származó merevítő hatását úgy küszöböli ki, hogy a jeges vezeték statikus egyensúlyi profilját megnövelt sürüségü vezeték- (rúd-) elemmel előzetesen meghatározzuk. Ennek a megváltozott statikus vezetékprofilnak a koordinátái képezik a jég-vezeték kompozit modell kiindulási alapját úgy, hogy a jég-vezeték kompozit modellben a vezetékelem kezdeti alakváltozását a megnövelt sürüségü vezetékelem alkalmazásával kapott számítási eredményből definiáljuk. A dinamikus vizsgálat az így kapott kompozit modell statikus egyensúlyi profiljának meghatározása után kezdődik meg az ADINA által biztosított, ún. „restart” alkalmazással. A vezetékre tapadt jég eltávolítására szánt ütés egy koncentrált, függőleges irányú impulzus típusú erő, melyet a dinamikus vizsgálat kezdetén alkalmazok (Kálmán 2007).

\subsection{A MODELL KORLÁTOZÁSAI}

A villamos energiaátviteli hálózatok gyakorlatilag négy fő komponenst tartalmaznak, melyek egymással összeköttetésben vannak: oszlopok, azok alapjai, szabadvezetékek, és egyéb összekötő elemek, mint pl. a szigetelők, hálózati szerelvények stb. A modell azonban a fejlesztés stádiumában csupán a jeges vezetéket veszi számításba, és elhanyagolja a többi komponens hatását, így a vezeték befogását tökéletesen merevnek tekinti. Végeztem modellfuttatásokat a vezeték, ill. a rögzítés rugalmasságának hatására vonatkozóan és ezeket az eredményeket összehasonlítottam laboratóriumi kísérletek eredményeivel (5. ábra) (Kálmán 2007). Ezek a vizsgálatok azt mutatták, hogy minél rugalmasabb a vezeték megfogása (ill. maga a rendszer), a vezetékről való jéghullás annál kisebb maximális vezetékugrást és a vezetékben ébredő maximális feszültséget eredményez. A jelen tanulmányban bemutatott alapmodell - az egyszerüség kedvéért - azonban úgy tekinti, hogy a vezeték befogása tökéletesen merev.

Az atmoszferikus jég mechanikai tulajdonságainak ismerete hiányában úgy gondoltam, hogy a jég törési kritériumának definiálására az édesvízi jégre jellemző tulajdonságok jó kiindulási alapot biztosíthatnak és azok bármikor helyettesíthetőek, amikor az atmoszferikus jég mechanikai tulajdonságai elérhetővé válnak (Kálmán 2007).

\subsection{A MODELLEN ALKALMAZOTT, ILLETVE A MODELLRE ÉPÜLÖ ÚJDONSÁGOK}

Mirshafiei tanulmányai során továbbfejlesztette a bemutatott modellt egy új jégtörési kritérium bemutatásával (Mirshafiei 2010; Mirshafiei et al. 2010). A modellezett jégre törési kritériumként egy maximális megengedett plasztikus alakváltozást 
definiált, és úgy tekintette, hogy amikor a plasztikus alakváltozás a számítás bármely integrációs pontján meghaladja a definiált értéket, akkor - a fentebb bemutatott jégtörés modellezésével azonos módon - az adott jég- (gerenda-) elem tömegét és merevségét a modell automatikusan törli a számításokból.

Az általam, ill. Mirshafiei által fejlesztett modellek azonban a ténylegesen bekövetkező jéghullást a valóságban bekövetkezőtől eltérő módon prognosztizálják (túlbecsülik), ugyanis nem veszik számításba a jég felülethez való tapadószilárdságát. Így ezek a modellek már akkor is úgy tekintik, hogy a jég a vezetékről lehullott, amikor azon a valóságban csak repedések keletkeztek, de az ugyanakkor még a vezetékhez tapad [laborkísérletek által tapasztalt összehasonlító eredmények (lásd Kálmán 2007; Mirshafiei 2010)]. A jég tapadószilárdságának meghatározására folytak kísérletek, de a tudástár még elég hiányos ezen a területen. Ennek ellenére e tulajdonság modellbe való integrálásával - melyre Mirshafiei kísérletet és ajánlást is tett - egy megbízhatóbb eszközhöz juthatunk.
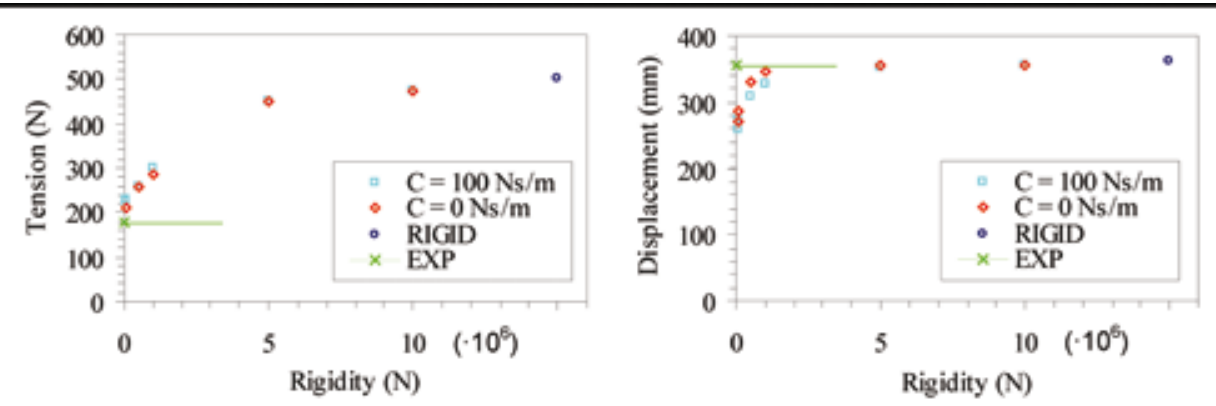

a) Maximális vezeték irányú feszültség

b) Maximális vezetékugrás
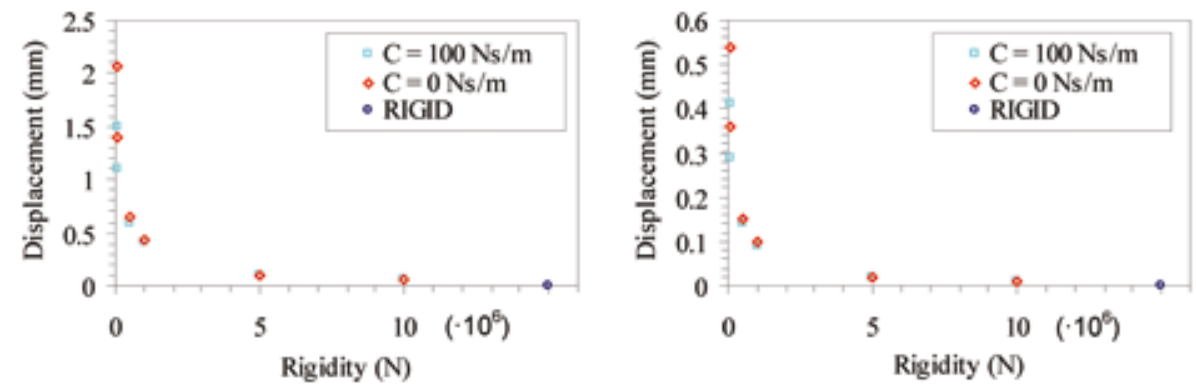

c) A vezeték tartóhoz való csatlakozási pontjának maximális horizontális irányú eltolódása

d) A vezeték tartóhoz való csatlakozási pontjának maximális vertikális irányú eltolódása

5. ábra. A tartó rugalmasságának hatása a laboratóriumi kísérlet során alkalmazott jeges vezeték fő paramétereinek modellezésével: $\mathrm{C}$ - tartó viszkózus csillapítása; RIGID - tökéletesen merev tartóra kapott modelleredmények; EXP - kísérletek során kapott eredmények (Forrás: Kálmán 2007) 
Hefny tanulmányozta a nedves hó vezetékről való lehullása okozta dinamikus hatásokat és ehhez szintén ADINA alkalmazásával végeselem-modellt készített, melynek során a nedves hó vezetékhez való tapadószilárdságát vette figyelembe (Hefny 2013). A nedves hó tapadószilárdságának (nyíró és húzó) megállapításához szintén kísérleteket végzett, és ennek eredményeit használta fel a modellfejlesztéshez. Annak ellenére, hogy az ő tanulmánya a nedves hó terhelésre koncentrál, alapjaiban hasonló megközelítéssel és ugyanazzal az eszközzel vizsgálja a témát, mint a fenti, jégterhelésre bemutatott modellek, és - ezeken túlmenően - figyelembe veszi a korábbi tanulmányok ajánlásait is. A nedves havat pontterhelésủ rugóelemekkel modellezi, melyeknek csupán a tömegét veszi számításba, míg a hó tapadására vonatkozó tulajdonságok egy másik, függőleges irányú rugóelemmel - csupán a merevségi paraméterek (tömeg és csillapítási tényezők nélkül) definiálásával veszi számításba, azonban a hóterhelés egyéb fizikai tulajdonságait a modell elhanyagolja.

\section{A MODELLFEJLESZTÉS LEHETSÉGES TOVÁBBI LÉPÉSEI}

Kermani részletesen tanulmányozta az atmoszferikus jég mechanikai tulajdonságait különböző környezeti körülmények (hömérséklet, relatív nedvességtartalom, szélsebesség stb.) között laboratóriumi szélcsatornában képződő jégdarabokon, különböző alakváltozási sebességek mellett (Kermani 2007; Kermani et al. 2008). Így a bemutatott modell egyik korlátozó tényezője, azaz az atmoszferikus jég mechanikai tulajdonságainak ismerete közelebb viheti a fejlesztőket egy megbízhatóbb jégtörési kritérium definiálásához.

Kombinálva a jeges vezetékre fejlesztett modelleket a bemutatott nedves hóval borított vezetékre fejlesztett modellel, és integrálva a jégre vonatkozó és elérhető mechanikai tulajdonságokat, valamint a tapadószilárdságra vonatkozó paramétereket, egy olyan modellhez juthatunk, mellyel komplex rendszerek jéghullásra adott dinamikus válaszai is jó közelítéssel, költséghatékonyan szimulálhatóak.

\section{KONKLÚZIÓ}

A bemutatott végeselem-modell jó kiindulási alapot szolgáltat ahhoz, hogy alkalmazásával a jeges távvezeték jéghullásra (akár spontán, akár generált) adott dinamikus válaszait tanulmányozzuk úgy, hogy figyelembe vesszük a jég mechanikai tulajdonságait. A bemutatott modell fejlesztése óta történtek új kutatások, és erre épülö újabb modellfejlesztések a témában. Azonban ezen eredmények, tapasztalatok egy modellbe való integrálása még várat magára.

Úgy gondolom, hogy ilyen típusú modellek alkalmazása hatalmas segítséget fog biztosítani a távvezeték hálózatok jégköri jegesedése okozta dinamikus terhelések 
megbecslésére és azok tervezéskori figyelembevételére annak érdekében, hogy az extrém időjárási körülmények során a légköri jegesedés okozta súlyos üzemzavarok elkerülhetőek legyenek.

\section{HIVATKOZOTT IRODALOM}

Hefny 2013

Index 2014

Jamaleddine et al. 1993

Kálmán 2007

Kálmán et al. 2005

Kálmán et al. 2007a

Kálmán et al. 2007b

Kermani 2007

Kermani et al. 2008

Leblond et al. 2005

McClure-Lapointe 2003

Mirshafiei 2010

Mirshafiei et al. 2010

Pekánovics et al. 2011
Hefny, R. M. H.: Numerical and experimental investigation of the influence of dynamic loads on wet snow shedding from overhead cables. Ph.D. Thesis. UQAC (Canada) 2013.

Hónapokig tart, amíg megjavítják a leszakadt vezetékeket. Index 2014.12. 02. http://index.hu/belfold/2014/12/02/honapokig_tart_amig_megjavitjak_a_leszakadt_vezetekeket (Utolsó megtekintés: 2015.10. 02.)

Jamaleddine, A. - McClure, G. - Rousselet, J. - Beauchemin, R.: Simulation of ice shedding on electrical transmission lines using ADINA. Computers and Structures 47 (1993) 4/5. 523-536.

Kálmán, T.: Dynamic behavior of iced cables subjected to mechanical shocks. Ph.D. Thesis. UQAC (Canada) 2007.

Kálmán, T. - Farzaneh, M. - McClure, G. - Kollár, L. E. - Leblond, A.: Dynamic behavior of iced overhead cables subjected to mechanical shocks. Proceedings of the 6th International Symposium on Cable Dynamics. Charleston (USA) 2005. 339-346.

Kálmán, T. - Farzaneh, M. - McClure, G.: Numerical analysis of the dynamic effects of shock-load-induced ice shedding on overhead ground wires. Computers and Structures 85 (2007) 375-384.

Kálmán, T. - Farzaneh, M. - McClure, G. - Leblond, A.: De-icing of overhead cables by mechanical shocks: numerical and experimental analyses. Proceeding of the 12th International Workshop on Atmospheric Icing on Structures. Yokohama (Japan) 2007. (in CD Proc.)

Kermani, M.: Ice shedding from cables and conductors - a cracking model of atmospheric ice. Ph.D. Thesis. UQAC (Canada) 2007.

Kermani, M. - Farzaneh, M. - Gagnon, R. E.: Bending strength and effective modulus of atmospheric ice. Cold Regions Science and Technology 53 (2008) 2. 162-169.

Leblond, A. - Lamarche, B. - Bouchard, D. - Panaroni, B. - Hamel, M.: Development of a portable de-icing device for overhead ground wires. Proceedings of the 11th International Workshop on Atmospheric Icing of Structures. Montréal (Canada) 2005. 399-404.

McClure, G - Lapointe, M.: Modeling the structural dynamic response of overhead transmission lines. Computers and Structures 81 (2003) 825-834. Mirshafiei, F.: Modelling the dynamic response of overhead line conductors subjected to shock-induced ice shedding. Master Thesis. McGill University, Montréal (Canada) 2010.

Mirshafiei, F. - McClure, G. - Kálmán, T. - Farzaneh, M.: Improved ice shedding modelling of iced cables: a comparison with experimental data. Proceeding of the 2nd International structural specialty conference, ISSC02. Winnipeg (Canada) 2010. 978-988.

Pekánovics L. - Tóth L. - Varga L.: Mechanikai biztosítós szerelvények alkalmazásával kapcsolatos kutatások és vizsgálatok. Elektrotechnika 12 (2011) 8-11. 
Roshan Fekr 1995

Szabó-Farkas 2009
Roshan Fekr, M.: Dynamic response of overhead transmission lines to ice shedding. Master Thesis. Department of Civil Engineering and Applied Mechanics. McGill University, Montréal (Canada) 1995.

Szabó Gy. - Farkas Gy.: 2009.01.27.-30. közötti idöszakban, Vas és Zala megyében tömeges üzemzavart okozó középfeszültségü (KÖF) oszlopok kitörési okainak, vezetékek szakadásának feltáró elemzése. Budapesti Műszaki és Gazdaságtudományi Egyetem, Budapest 2009.

\title{
NUMERICAL ANALYSES OF OVERHEAD TRANSMISSION CABLES EXPOSED TO ATMOSPHERIC ICING
}

\begin{abstract}
Summary
In countries where atmospheric icing often causes serious damages to engineering structures, strong effort is taken to increase the in-depth knowledge of this phenomenon and to develop methods to prevent the occurrence of catastrophic events or at least to mitigate their effect. One segment of these engineering structures exposed to atmospheric icing belongs to the electric power distribution and transmission system. In winter season, heavy adherent wet snow, hard rime, large but lightweight rime ice, and dense glaze ice deposited on overhead transmission lines are often responsible for damages of supporting structures or other line components. This study is aimed to provide a general introduction about atmospheric icing affecting overhead transmission lines and a de-icing technique of interest that uses mechanical shocks to remove accreted ice from the cable. The author developed a finite element model for an iced span section that calculates the dynamic effects of shock-load-induced ice-shedding and explicitly considers the rupture criteria of glaze ice. The author used the results of his Ph.D. studies carried out in Canada, within the framework of CIGELE to compile this paper and integrated new scientific evidences that have been achieved in the subject.
\end{abstract}

Keywords: overhead transmission line, atmospheric icing, dynamic analysis, finite element model 